\title{
Iğdır Ekolojik Şartlarında Bazı Macar Fiğ (Vicia pannonica Crantz) Çeşitlerinin Verim ve Verim Komponentlerinin Belirlenmesi
}

\author{
Fikret Budak $^{19}$ \\ ${ }^{1}$ Düzce Üniversitesi Ziraat ve Doğa Bilimleri Fakültesi Tarla Bitkileri Bölümü, Konuralp/Düzce \\ $\triangle$ : fikretbudak@duzce.edu.tr
}

Geliş (Received): 02.11.2017

Kabul (Accepted): 15.12.2017

\begin{abstract}
ÖZET: Çalışma 2011-2012 ve 2012-2013 yıllarında iki yıl süreyle Iğdır ili Karakoyunlu ilçesi çiftçi şartlarında, en uygun Macar fiğ çeşitlerinin (Tarm Beyazı, Ege Beyazı, Oğuz, Budak, Beta, Pembesi ve Altınova) belirlenmesi amacı ile yürütülmüsstür. Deneme Tesadüf Blokları Deneme Desenine göre dört (4) tekrarlamalı olarak yürütülmüştür. Yaş ot bakımından fiğ çeşitleri arasında 2011 yılında farklılıklar istatiksel açıdan önemli çıkmazken 2012 yılında ve iki yıllık ortalamalarda önemli olmuştur. Kuru ot, tohum verimi yönünden farklılıklar yıllar bazında önemli olmazken iki yıllık ortalamalarda çeşitler arasında fark önemli bulunmuştur. İki yıllık ortalama sonuçlara göre, yaş ot verimi 2607-3107 $\mathrm{kg}$ da-1, kuru ot verimi 644.7-741.3 kg da-1, tohum verimi 86.09-101.1 kg da-1 ve kuru otta ham protein oranı \% 18,87-20,05 arasında değişim göstermiştir.

Anahtar Kelimeler: Macar fiğì, çeşit, verim, verim unsurları
\end{abstract}

\section{Determination of Yield and Yield Components of Some Hungarian Vetch Varieties in Iğdır Ecological Condition}

ABSTRACT: The study was carried out in 2011-2012 and 2012-2013 for two years in order to determine the best Hungarian vetch varieties in Iğdır Karakoyunlu county farmer conditions. The experiment was designed according to the Random Blocks Experimental Design with four replications. There were differences among the vetch varieties in terms of herbage, hay, seed yield and crude protein ratio, According to the two years average results, the herbage yield between $2607-3107 \mathrm{~kg}$ da-1, hay yield $644.7-741.3 \mathrm{~kg}$ da-1, and $86.09-101.1 \mathrm{~kg}$ da-1 the seed yield 75,17$111.3 \mathrm{~kg}$ da-1, the crude protein rate 16,01-19.42 varied.

Key words: Hungarian vetch, variety, yield, yield components

\section{GIRISS}

Ülkemizde yem bitkileri tarımı ve üretiminin yetersizliği nedeniyle birçok bölgede özellikle amatör hayvan yetiştiriciliği yapan çiftçiler besin kaynağı olarak genellikle tabii çayır meraları kullanmaktadır. Bu sebeple uzun yıllar düzensiz ve aşırı otlatmaya maruz kalan çayır meralar yıpranmış ve verimleri düşmüştür. Dolayısıyla bu alanlardan yeterince ve kaliteli beslenemeyen hayvanların verimleri de aynı şekilde düşmüştür. Zira çayır ve meralar üzerindeki hayvan sayısını azaltmadan çayır mera ıslahının yapılabilmesi söz konusu değildir. Bu alanların ıslahı için çözülmesi gereken en önemli problemlerden biri hayvanların kaba yem ihtiyacının düzenli olarak karşılanmasıdır. Yem bitkilerinin önemi hayvansal ürünlerde görülmektedir. Besleme değeri, özellikle protein oranı yüksek yemlerle beslenen hayvanlar daha kaliteli ürün verecekleri için hem insan sağlığı hem de ülke ekonomisi için büyük önem arz etmektedir.

Ülkemizde bölge ekolojik ve yetiştirme şartlarına bağlı olarak ortalama $1000-5000 \mathrm{~kg} \mathrm{da}^{-1}$ yaş ot, 300$1000 \mathrm{~kg} \mathrm{da}^{-1}$ kuru ot verimi ve ortalama \% 15-22 ham protein oranına sahip yüksek kaliteli tek yıllık Macar fiği çeşitleri mevcuttur. Ancak bu tür çeşitlerin ekim alanlarının ve üretiminin ülkemiz hayvancılığının kaba yem ihtiyacını karşılamaktan çok uzak olduğu açıkça görülmektedir. Ülke ve bölge hayvancılığımızın en önemli sorunlarından biri olan kaliteli kaba yem açığını kapatmada, yeşil ve kuru otu ile katkı sağlayan Macar fiği, aynı zamanda yeşil gübre bitkisi olarak ta önem arz etmektedir. Ayrıca, tane verimi için hasat edilen bitkilerden arta kalan samanı da iyi bir hayvan yemidir (Açıkgöz, 2001). Macar fiği kışa dayanıklı, kurağa toleranslı ve verimi yüksek tek yıllık yem bitkisidir. Iğdır ilinde tarımsal ve hayvansal üretimden geçimini sağlayan nüfusun fazla olmasına rağmen istenilen üretim değerlerine ulaşmakta sıkıntı yaşamaktadır. 2012 y1lı sonu itibariyle 130.055 büyükbaş hayvan ve 595.000 adet küçükbaş hayvan sayısına karşılık gelen 158.564 BBHB için gerekli olan kaliteli kaba ot üretimi 578.756 ton olmas1 gerekirken 124.238 tonluk kaliteli kaba ot üretimi gerçekleşmiştir. Diğer bir deyişle 454.518 ton kaliteli kaba ot açı̆̆ 1 oluşmaktadır. Görüldüğü üzere Iğdır ili ihtiyaçlarını karşılamaktan uzak olan bu tablonun düzeltilmesi için çayır mera alanlarının ıslah ve amenajman çalışmaları ile mevcut yapısının iyileştirilmesi, aşırı ve düzensiz otlatmanın önüne geçilmesi ve en önemlisi üreticilerin bu konularda bilgilendirilme ve bilinçlendirilmesi gerekmektedir (Budak, 2013).

Ülkemizde toplam fiğ ekim alanları 2012 yılında 670.000 hektar iken 2016 y1l itibariyle 495.514 hektar alana bir önceki yılda 67.385 ton üretim yapılırken bu rakam 2016 yılında \% 0,6 düşüş ile 66.987 ton olarak kaydedilmiştir (Anonim, 2017.) Kaba yem üretiminin mevcut hayvanların varlığının ihtiyacını karşılama oranı 
ise ancak \% 9 dur. Buda hayvanlarımız yeterince ve kaliteli olarak beslenemediğinin açık bir göstergesidir.

$\mathrm{Bu}$ konuda daha önce yapılmış olan çalışmalarda; Orak ve Nizam (2003) Trakya bölgesinde Macar fiğinde tohum verimini $68.43-97.29 \mathrm{~kg} \mathrm{da}^{-1}$, Uzun ve ark.(2004) Bursa şartlarında Macar fiğinin tohum verimini 50.50$140.30 \mathrm{~kg} \mathrm{da}^{-1}$, olarak bildirmişlerdir. Sayar ve ark (2010) ise Diyarbakır şartlarında tohum verimini 68.33$98.66 \mathrm{~kg} \mathrm{da}^{-1}$ olarak bildirmektedirler. Eskişehir İlinde nadasa bırakılan alanlarda yapılan bir çalışmada tek yıllık macar fiğ ve hububat karışımlarında yaş ot verimlerinin (3.412 $\left.\mathrm{kg} \mathrm{da}^{-1}\right)$ oldukça yüksek olduğu ve hayvanların dengeli beslenmesindeki önemi vurgulanmıştır (Budak 2011).Erzurum ekolojik koşullarında yetiştiren Macar fiği genotiplerinde kuru ot veriminin ise 433.8-452.7 $\mathrm{kg} \mathrm{da} \mathrm{da}^{-1}$ arasında değiştiği bildirilmiştir (Tahtacıoğlu, 1996). Erzurum koşullarında yapılan başka bir çalışmada Macar fiğinde kuru ot verimi 586.0-761.2 $\mathrm{kg} \mathrm{da}^{-1}$ olarak bildirilmiştir (Taş N., 2007). Kayseri ekolojik koşullarında farklı ekim zamanlarının bazı fiğ çeşitlerinin verimlerine etkisini araştırmak için yapılan bir çalışmada macar fĭg çeşidinin 910,81-981,21 kg da ${ }^{-1}$ tohum verimin 213,80$259,52 \mathrm{~kg} \mathrm{da}^{-1}$, ve ham protein oranlarının ise \% 20,2320,49 arasında değiştiği vurgulanmıştır (Budak ve ark.,1997). Ankara koşullarında Macar fiğinin 1994 ve 1995 yıllarında sırasıyla ortalama yeşil ot veriminin $1586.0-1632.52 \mathrm{~kg} \mathrm{da}^{-1}$, kuru ot veriminin ise 425.01$508.21 \mathrm{~kg} \mathrm{da}^{-1}$ olduğu rapor edilmiştir (Kendir H., 1996). Ankara koşullarında kışlık yetiştirilen fĭg çeşitlerinin yem verimleri ile ilgili yürütülen 2 yıllık (1994-95) araştırmada Macar fiğinin yaş ot ve kuru ot verimleri sirasiyla1609.3 ve $466.6 \mathrm{~kg} \mathrm{da}^{-1}$ olarak bildirilmiştir (Sevimay ve Kendir,1996). Trakya bölgesi koşullarında Macar fiği hatlarının ortalama yeşil ot veriminin $1594.30-1644.0 \mathrm{~kg} \mathrm{da}^{-1}$ ve kuru ot veriminin 456.12-510.92 $\mathrm{kg} \mathrm{da}^{-1}$ olduğu bildirmiştir (Orak, A., 2003). Amik ovasında koşullarında Ege beyazı-79 Macar fiği çeşidinde bitki boyunun $44.33 \mathrm{~cm}$, yeşil ot veriminin $2985.0 \mathrm{~kg} \mathrm{da}^{-1}$ ve kuru ot veriminin 405.33 $\mathrm{kg} \mathrm{da}^{-1}$ olduğu saptanmıştır. (Yılmaz Ş., 1996). Bursa koşullarında yapılan diğer bir araştırmada kuru madde veriminin 390.8-452.7 $\mathrm{kg} \mathrm{da}^{-1}$, tohum veriminin 97,3$100,8 \mathrm{~kg} \mathrm{da}^{-1}$ olduğunu bildirilmiştir (Uzun A., 2004). Ankara koşullarında macar fiğin bakteri aşılaması ve gübre dozları konusunda yapılan bir çalışmada yaş ot veriminin dekara $1578.3-2147.6 \mathrm{~kg}$, kuru ot veriminin 434.6-600.6 kg ve ham protein oranlarının ise \%13.819.6 arasında olduğu bildirilmiştir. (Ünver ve ark., 2000).
Tokat koşullarında yapılan bir çalışmada Macar fiği çeşidinin ortalama tohum verimin $114,1 \mathrm{~kg} \mathrm{da}^{-1}$ olduğu gösterilmiştir (İptaş, 2002). Sirbistan'da macar fiğinin en uygun sıra arası ekimlerinin tespiti için yapılan bir çalışmada 12,5 ve $50 \mathrm{~cm}$ sıra aralıklarında tohum veriminin sirasiyla $119,9 \quad-156,0 \quad \mathrm{~kg} \quad \mathrm{da}^{-1}$ olduğu bildirilmiştir (Đura, K., ve ark., 2011)

$\mathrm{Bu}$ çalışma Iğdır ekolojik koşullarında tescilli bazı Macar fiği çeşitlerinin verim ve verim unsurları bakımından en uygun fiğ çeşidini belirlemek ve yörede yem bitkileri yetiştiriciliğini teşvik etmek amacıyla yürütülmüştür.

\section{MATERYAL ve METOT}

Araştırma 2011-2012 ve 2012-2013 yıllarında iki yıl süreyle Iğdır ili Karakoyunlu ilçesi çiftçi şartlarında, tescilli Macar fiğ çeşitlerinden (Tarm Beyazı, Ege Beyazı, Oguz, Budak, Beta, Anadolu Pembesi ve Altınova) yöreye en uygun çeşidin belirlenmesi amacı ile yürütülmüştür.

Deneme Tesadüf Blokları Deneme Desenine göre dört (4) tekrarlamalı olarak yürütülmüştür. Dekara $8 \mathrm{~kg}$ tohum kullanılmıştır. Denemede parsel alanı ekimde: $0.25 \times 6 \times 5=7.5 \mathrm{~m}^{2}$ ve hasatta ise: $0.25 \times 6 \times 4=6 \mathrm{~m}^{2}$ ) olacak şekilde planlanmıştır. Dekara14 kg DAP (Diamonyum Fosfat) taban gübresi atılmıștır. Ekimler 15 Eylül 2011 ve 14 Eylül 2012 tarihlerinde iki yıl sürdürülmüsstür. Vejatetasyon döneminde bitkiler 2 defa sulanmıştır. Hasatlar yeşil ot için \% 50 çiçeklenmede ve kenar tesirler atıldıktan sonra 4 sira parselin yarıs1, tohum için baklaların 3-4 baklanın tümüyle sarardığg dönemde parselin diğer yarısı (4 sıra) hasat edilerek tohum verimi bulunmuştur. Kuru ot değerlerinin belirlenmesinde parsellerden rastgele alınan 500 g.' l1k yeşil ot örnekleri kurutma dolabında $70{ }^{\circ} \mathrm{C}$ 'de 48 saat süreyle kurutularak 24 saat bekledikten sonra hassas terazide tartılarak kuru ot ağırlığı bulunmuştur. Kuru ot oranları dikkate alınarak dekara kuru ot verimi hesaplanmıştır.

Ortalamalar arasındaki farklılıkların istatistiki anlamda önemlilikleri Duncan testi yapılarak belirlenmiştir.

Çalışmaların yapıldığg dönemde yıllara göre toprak bünyesi killi-tınlı bir yapıya sahip olup, hafif alkali, derinliklere $(30-60 \mathrm{~cm})$ göre sirasıyla kireç $(\% \quad 0.07-$ $0.09)$, tuzluluk (0.641-0.757) orta, organik madde (1.15 -1.49 ) orta, fosfor (10.03 -11.09 ppm) orta ve potasyum (145.7-187 ppm) orta derecededir (Çizelge.1). Ortalama yıllık yağış miktarı ve sıcaklık dereceleri 2 yılda da benzerlik göstermiştir (Çizelge.2).

Çizelge 1. 2011-2012 Yıllarına Ait Toprak Analiz Sonuçları *

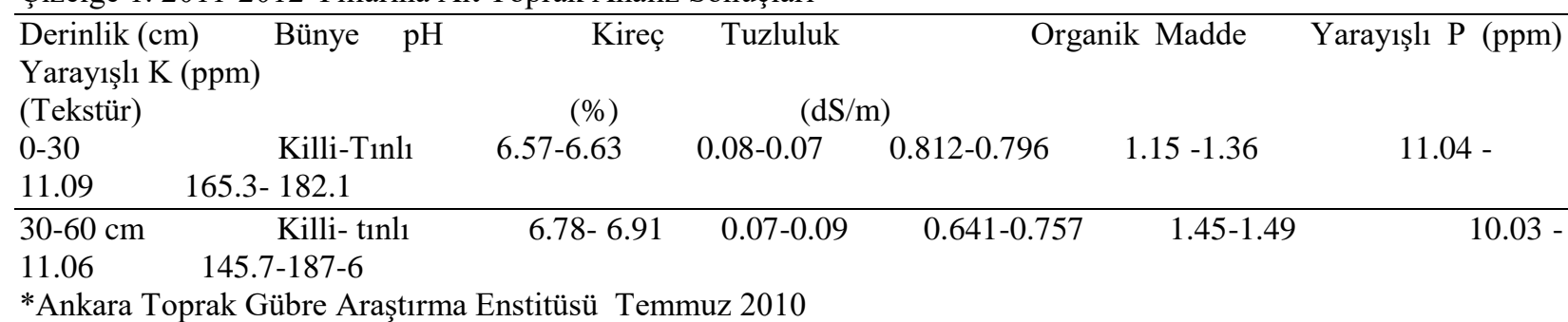


Cizelge 2. 2011- 2012 ve Uzun Y1llara (1940-2016) Ait İklim Değerleri

\begin{tabular}{lcccccc}
\hline \multirow{2}{*}{ Yıllar/Aylar } & \multicolumn{3}{c}{ Ortalama Sıcaklık (oC) } & \multicolumn{3}{c}{ Toplam Yağıș (mm) } \\
\cline { 2 - 7 } & $\mathbf{2 0 1 1}$ & $\mathbf{2 0 1 2}$ & U.Y & 2011 & $\mathbf{2 0 1 2}$ & U.Y \\
\hline Ocak & 2,4 & 0,6 & $-3,3$ & 6.0 & 0.0 & 15,1 \\
\hline Şubat & $-4,3$ & $-2,5$ & $-0,3$ & 22,06 & 12,5 & 16,3 \\
\hline Mart & 15.4 & 9,7 & 6,4 & 16,8 & 13,5 & 22 \\
\hline Nisan & 13,9 & 15,05 & 13,3 & 73,9 & 16,2 & 34,1 \\
\hline Mayis & 18,7 & 20,4 & 17,9 & 76,9 & 57,4 & 46,4 \\
\hline Haziran & 24,5 & 24,35 & 22,2 & 40,4 & 26,7 & 32,6 \\
\hline Temmuz & 28.15 & 25,25 & 25,9 & 24,0 & 23,0 & 13,9 \\
\hline Ağustos & 25,7 & 26,55 & 25,2 & 24,3 & 0,6 & 9,5 \\
\hline Eylül & 20,4 & 20,5 & 22,1 & 10,6 & 29,3 & 11 \\
\hline Ekim & 15,2 & 17 & 12,8 & 23,8 & 11,5 & 26,1 \\
\hline Kasım & 7,5 & 18,3 & 5,8 & 9,2 & 20,7 & 18,1 \\
\hline Aralık & $-1,9$ & 2,6 & $-0,4$ & 9,1 & 25,8 & 13,5 \\
\hline
\end{tabular}

\section{BULGULAR VE TARTIŞMA}

Denemeye alınan 7 Macar fiğ çeşidinde yaş ot, kuru ot, tohum verimi ve Protein oranına ilişkin varyans analizi ve ortalamalar sırasıyla Çizelge 3 ve 4'de verilmiştir.

Çeşitlerin iki yıllık yaş ot verim ortalamaları 2607 $3107 \mathrm{~kg} \mathrm{da}^{-1}$ arasında değişmiştir. Yapılan istatistik analiz sonucunda 2 grup oluşmuştur. Altınova, Anadolu Pembesi, Ege Beyazı ve Budak çeşitleri aynı grupta,
Tarm Beyazı, Oguz ve Beta çeşitleri ikinci grupta yer almıştır. Budak ve ark. (2011)'nın yaptıkları çalışmalarda bildirdikleri değerlerle uyum içerisinde iken Kendir ve ark. (1996) ve Ünver ve ark. (2000)'nın rakamlarından daha yüksek bulunmuştur. Araştırmacıların bulguları arasındaki farklılıklar genotip, iklim ve toprak özelliklerinden kaynaklanmış olabilir.

Çizelge 3.Yıllar İçin Yapılan Birleştirilmiş Tesadüfi Bloklar Varyans Analizi

\begin{tabular}{|c|c|c|c|c|c|c|c|c|c|}
\hline \multirow[t]{2}{*}{ V.K } & \multirow[t]{2}{*}{ S.D } & \multicolumn{2}{|c|}{ Yaş Ot Verimi } & \multicolumn{2}{|c|}{ Kuru Ot Verimi } & \multicolumn{2}{|c|}{ Tohum Verimi } & \multicolumn{2}{|c|}{ Protein Oranı } \\
\hline & & O.K & $\mathbf{F}$ & O.K & $\mathbf{F}$ & O.K & $\mathbf{F}$ & O.K & $\mathbf{F}$ \\
\hline Yll & 1 & 3174.95 & $0.09^{\mathrm{ÖD}}$ & 2131.36 & $0.57^{\mathrm{O} D}$ & 12.59 & $0.12^{\mathrm{OD}}$ & 4.40 & $2.72^{\mathrm{OD}}$ \\
\hline $\begin{array}{l}\text { Yilların } \\
\text { Hatası }\end{array}$ & 6 & 35058.38 & & 3725.34 & & 99.64 & & 1.61 & \\
\hline Çeşit & 6 & 293175.22 & $13.93 * *$ & 10243.71 & $6.50 * *$ & 236.32 & $2.89 *$ & 1.93 & $1.00^{\mathrm{ÖD}}$ \\
\hline $\begin{array}{l}\text { Yll } \times \\
\text { Cesit }\end{array}$ & 6 & 16836.18 & $0.80^{\mathrm{OD}}$ & 5520.34 & $3.50 * *$ & 32.28 & $0.39^{\circ \ddot{D}}$ & 0.549 & $0.28^{\mathrm{ÖD}}$ \\
\hline Hata & 36 & 21044.89 & & 1575.75 & & 81.57 & & 1.92 & \\
\hline Genel & 55 & & & & & & & & \\
\hline CV\% & & 5 . & & & & & & & \\
\hline
\end{tabular}

$\mathrm{P}<0.01, * \mathrm{P}<0.05$

Kuru ot değerleri bakımından Çeşit ve yıl $\times$ çeşit interaksiyonu istatistiki açıdan $\mathrm{P}<0.01$ seviyesinde önemli bulunmuştur. İki yıllık ortalama değerlere göre kuru ot verimleri 644.7-741.3 $\mathrm{kg} \mathrm{da}^{-1}$ arasinda değişmiştir. Altınova çeşidi $741.3 \mathrm{~kg} \mathrm{da}^{-1}$ ile en yüksek kuru ot verimine sahipken en düşük $644.7 \mathrm{~kg} \mathrm{da}^{-1}$ değer ile Oguz çeşidinden elde edilmiştir. Bulgularımız Taş ve ark. (2007) ve Ünver ve ark (2000)'nın buldukları değerlerle uyum içerisinde olurken Tahtacıoğlu ve ark. (1996)'nın bildirdikleri değerlerden daha yüksek bulunmuştur. $\mathrm{Bu}$ farklılık genotip, iklim ve toprak özelliklerinden kaynaklanmış olabilir.

Çeşitlerin ortalama tohum verimleri $86.09-101.1 \mathrm{~kg}$ $\mathrm{da}^{-1}$ arasında değişmiştir. En yüksek tohum verimi
Anadolu Pembesi çeşidinden alınırken en düşük değer ise Budak çeşidinden alınmıştır. Çeşitler arasındaki fark istatiksel olarak $\mathrm{P}<0.05$ seviyesinde önemli olmuştur. Bulgularımız Orak ve Nizam (2003), Uzun ve ark.(2004), Sayar ve ark. (2010) bildirdikleri değerlerle uyum içerisinde olmuştur.

Çeşitlerin ortalama protein oranları \% 18.87- 20.05 arasında değişim göstermiştir. Çeşitler arasındaki fark istatiksel olarak önemli olmamıştır. Bunun nedeninin varyasyon kaynaklarının benzer olasından ve aynı dönemde biçim yapılmasından kaynaklanmış olduğu ihtimaldir. Elde edilen bulgular Ünver ve ark (2000)' nın bulguları ile uyum içerisinde olmuştur. 
Çizelge. 4. Çeşitlerin Ortalama Verimlere Ait Duncan Analiz Tablosu

\begin{tabular}{|c|c|c|c|c|c|c|c|c|c|c|c|c|}
\hline \multirow[t]{2}{*}{ Çeşitler } & \multicolumn{3}{|c|}{ Yaş Ot $\left(\mathrm{kg} \mathrm{da}^{-1}\right)$} & \multicolumn{3}{|c|}{ Kuru Ot $\left(\mathrm{kg} \mathrm{da}^{-1}\right)$} & \multicolumn{3}{|c|}{ Tohum Verimi $\left(\mathrm{kg} \mathrm{da}^{-1}\right)$} & \multicolumn{3}{|c|}{$\begin{array}{l}\text { Protein Oranı } \\
(\%)\end{array}$} \\
\hline & 2011 & 2012 & Ort. & 2011 & 2012 & $\begin{array}{l}\text { Ortalam } \\
\text { a }\end{array}$ & 2011 & 2012 & $\begin{array}{l}\text { Ortalam } \\
\text { a }\end{array}$ & $\begin{array}{c}201 \\
1 \\
\end{array}$ & $\begin{array}{c}201 \\
2\end{array}$ & Ort \\
\hline Tarm & 2538. & 2675. & 2607 & 630.2 & 660.6 & & & & 93.39 & 19.1 & 18.7 & 18.9 \\
\hline Beyazı & 58 & 21 & B & $\mathrm{c}$ & $\mathrm{bc}$ & $645.4 \mathrm{C}$ & 96.28 & 90.48 & $\mathrm{ABC}$ & 2 & 9 & 5 \\
\hline Ege Beyazı & $\begin{array}{l}2992 . \\
76\end{array}$ & $\begin{array}{l}3006 . \\
06\end{array}$ & $\begin{array}{l}2999 \\
\text { A }\end{array}$ & $\begin{array}{l}669.0 \\
\mathrm{bc}\end{array}$ & $\begin{array}{l}692.2 \\
\mathrm{bc}\end{array}$ & $680.6 \mathrm{BC}$ & 88.17 & 90.1 & $89.14 \mathrm{BC}$ & $\begin{array}{l}18.5 \\
4 \\
\end{array}$ & $\begin{array}{l}19.3 \\
4 \\
\end{array}$ & $\begin{array}{l}18.9 \\
4 \\
\end{array}$ \\
\hline Oguz & $\begin{array}{l}2702 . \\
61\end{array}$ & $\begin{array}{l}2788 . \\
98\end{array}$ & $\begin{array}{l}2746 \\
\text { B } \\
\end{array}$ & $\begin{array}{l}627.5 \\
\mathrm{c}\end{array}$ & $\begin{array}{l}662.0 \\
\mathrm{bc}\end{array}$ & $644.7 \mathrm{C}$ & 94.69 & 98.98 & $\begin{array}{l}96.84 \\
\mathrm{AB}\end{array}$ & $\begin{array}{l}18.5 \\
9\end{array}$ & $\begin{array}{l}19.9 \\
1\end{array}$ & $\begin{array}{l}19.2 \\
5 \\
\end{array}$ \\
\hline Budak & $\begin{array}{l}2995 . \\
74\end{array}$ & $\begin{array}{l}2923 . \\
68\end{array}$ & $\begin{array}{l}2960 \\
\text { A }\end{array}$ & $\begin{array}{l}730.6 \\
\mathrm{ab}\end{array}$ & $\begin{array}{l}667.2 \\
b c\end{array}$ & $\begin{array}{l}698.9 \\
\mathrm{ABC}\end{array}$ & 86.16 & 86.01 & $86.09 \mathrm{C}$ & $\begin{array}{l}18.7 \\
0\end{array}$ & $\begin{array}{l}19.0 \\
4\end{array}$ & $\begin{array}{l}18.8 \\
7\end{array}$ \\
\hline Beta & $\begin{array}{l}2657 . \\
00\end{array}$ & $\begin{array}{l}2746 . \\
35\end{array}$ & $\begin{array}{l}2702 \\
\mathrm{~B} \\
\end{array}$ & $\begin{array}{l}647.9 \\
\mathrm{bc}\end{array}$ & $\begin{array}{l}668.0 \\
\mathrm{bc}\end{array}$ & $657.9 \mathrm{BC}$ & 86.95 & 87.33 & $87.14 \mathrm{BC}$ & $\begin{array}{l}19.7 \\
4 \\
\end{array}$ & $\begin{array}{l}20.0 \\
5 \\
\end{array}$ & $\begin{array}{l}19.0 \\
3 \\
\end{array}$ \\
\hline Altınova & $\begin{array}{l}3158 . \\
24 \\
\end{array}$ & $\begin{array}{l}3055 . \\
54\end{array}$ & $\begin{array}{l}3107 \\
\text { A }\end{array}$ & $\begin{array}{l}789.7 \\
\mathrm{a} \\
\end{array}$ & $\begin{array}{l}692.9 \\
\mathrm{bc}\end{array}$ & $741.3 \mathrm{~A}$ & 97.27 & 90.41 & $\begin{array}{l}93.84 \\
\mathrm{ABC}\end{array}$ & $\begin{array}{l}18.5 \\
3 \\
\end{array}$ & $\begin{array}{l}19.4 \\
3 \\
\end{array}$ & $\begin{array}{l}18.9 \\
8 \\
\end{array}$ \\
\hline $\begin{array}{l}\text { Andolu } \\
\text { Pemb }\end{array}$ & $\begin{array}{l}3055 . \\
69\end{array}$ & $\begin{array}{l}3010 . \\
22\end{array}$ & $\begin{array}{l}3033 \\
\text { A }\end{array}$ & $\begin{array}{l}723.0 \\
\text { ab }\end{array}$ & $\begin{array}{l}688.7 \\
\mathrm{bc}\end{array}$ & $\begin{array}{l}705.9 \\
\mathrm{AB}\end{array}$ & $\begin{array}{l}101.3 \\
6\end{array}$ & $\begin{array}{l}100.9 \\
2\end{array}$ & $101.1 \mathrm{~A}$ & $\begin{array}{l}19.7 \\
5\end{array}$ & $\begin{array}{l}20.3 \\
4 \\
\end{array}$ & $\begin{array}{l}20.0 \\
5\end{array}$ \\
\hline Ortalama & $\begin{array}{l}2871 . \\
52\end{array}$ & $\begin{array}{l}2886 . \\
58\end{array}$ & & $\begin{array}{l}688.2 \\
7 \\
\end{array}$ & $\begin{array}{l}675.9 \\
4 \\
\end{array}$ & & 92.98 & 92.03 & & $\begin{array}{l}19.0 \\
2\end{array}$ & $\begin{array}{l}19.5 \\
6\end{array}$ & \\
\hline LSD \% 1 & & & 197.3 & 76.33 & & 53.98 & & & 9.159 & & & \\
\hline
\end{tabular}

Küçük haflar satır ve sütunlarda yer alan yıllar ve çeşitlerin interaksyonuna ait olan Duncan analizi

Büyük Harflar Sutunlara ait olan Duncan analizi

\section{SONUC}

Iğdır ekolojik şartlarına uygun Macar fiğ çeşitlerin belirlenmesi amacıyla 7 farklı Macar fĭğ çeşidi ile yürütülen bu çalışmada; iki yıllık verilere göre, yeşil ot ve kuru ot verimleri birlikte dikkate alındığında Altınova çeşidi en yüksek verimli olduğu bunu sırasıyla Anadolu pembesi ve Budak çeşitlerinin izlediği görülmüştür. Tohum verimleri dikkate alındığında en yüksek verim Anadolu pembesi çeşidinden alınırken bunu sırasıyla Oğuz ve Tarm Beyazı izlemiștir. Ham protein oranları dikkate alındığında ise rakamsal olarak Anadolu pembesi çeşidi en yüksek değere sahip olmuştur. Bu araştırma sonucuna göre, Iğdır ili iklim ve toprak koşullarında tarla tarımı içerisinde özellikle kışlık olarak Macar fiğ yetiştiriciliğinin iyi sonuçlar vereceği belirlenmiş̧tir. Macar fiğ baklagiller familyasına ait olması dolayısıyla münavebeye girecek diğer bitkilere iyi bir toprak, iyi bir tohum yatağı bırakacak, hayvanlara kaliteli beslenmesini için yem katkısında bulunacaktır. Ayrıca tohum üretimi yapılarak ek gelir elde edilebilecektir.

Ülke Hayvancilığının, kaliteli et ve süt üretiminin gerçekleşebilmesi için kışı 1lıman geçen ve yıllık yağışı 400 mm'nin üzerinde olan bölge ve illerimiz için yaygın fiğ çeşitleri, diğer bölge ve iller için ise özellikle kışa, kurağa ve soğuğa dayanıklı verimi ve kalitesi yüksek tek yıllık Macar fiğ çeşitlerinden ve özellikle Iğdır yöresi için Altınova, Anadolu Pembesi ve Budak çeşitlerinin yetiştirilmesi tavsiye edilir.

\section{KAYNAKLAR}

Anonim 2013. Meteroloji Genel Müdürlüğü.

https://www.mgm.gov.tr/veri degerlendirme /il-veilceler-istatistik.aspx?k
Anonim 2016. Türkiye istatistik Kurumu.http://tuik.gov.tr/PreTablo.do?alt_id=1001 (Erişim Tarihi, 05.05. 2017.

Budak F, Büyükburç U, Budak H 1997 . Kayseri Ekolojik Koşularında Farklı Ekim Zamanlarının Bazı Fĭ̆ (vicia sp.) Türlerinin Tarımsal Özelliklerine Etkisi Üzerine Bir Araştirma. OMÜ Ziraat Fakültesi Tarla Bitkileri Bölümü Tarla Bitkileri Derneği Türkiye II. Tarla Bitkileri Kongresi. Samsun,1997.

Budak, F, Tükel T, Hatipoğlu R 2011. Possibilities of Growing Vetch and Cereals Mixtures in Fallow Fields in Eskişehir Condition. The Journal of Animal\&Plant Sciences 21(4): Page:724-729,ISSN 1018-7081.

Budak F 2013. Iğdır İli Çayır-Mera ve Yem Bitkilerinin Durumu, Hayvan Beslenmesinde Önemi. Tarım Bilimleri Araştırma Dergisi 6 (2): 49-55, 2013 ISSN: $1308-3945$, E-ISSN: 1308-027X, www.nobel.gen.tr

Đura K, Vojislav M, Slobodan K, Aleksandar M, Dragan M, Sanja V, Branko M 2011. Romanian Agricultural Research, NO. 28, www.incdafundulea.ro Print ISSN 1222-4227; Online ISSN 2067-5720

İptaş S 2002. Effect of Row Spacing, Support Plant And Mixture Ratio on The Seed Yield And Some Yield Characteristics of Hungarian Vetch. J. Agron. and Crop Sci., 118: 357-362.

Kendir H, Sevimay CS 1996. Ankara Koşullarında Kışlık Yetiştirilen Fiğ Çeşitlerinin Yem verimleri. Türkiye 3. Çayır-Mera ve Yem bitkileri Kongresi, 17-19 Haziran, Erzurum, s:472-478 
Orak A, Nizam İ 2003. Trakya Bölgesinde Macar Fiği (Vida pannonica Crantz.)

Hatlarının Önemli Bazı Verim ve Verim Unsurlarının Belirlenmesine İlişkin Bir Araştırma. Türkiye 5. Tarla Bitkileri Kongresi, 13-17 Ekim, Diyarbakır, Cilt I Tarla Bitkileri Islahı, s: 331-335

Sevimay CS, Kendir H 1996. Ankara Koşullarında Kışlik Yetiştirilen Fiğ Çeşitlerinin Yem Verimleri. Türkiye 3. Çayır-Mera ve Yem Bitkileri Kongresi 17- 19 Haziran 1996, s: 472-478, Erzurum

Tahtacıŏlu L, Avcı M, Mermer A, Şeker H, Aygün C 1996. Bazı Kışlık Fiğ Çeşitlerinin Erzurum Ekolojik Koşullarına Adaptasyonu. Türkiye 3. Çayır-MeraYem bitkileri Kongresi, 17-19 Haziran, Erzurum, s: 661-667.

Uzun A., Bilgili U, Sincik M, Açıkgöz E 2004. Effect of Seeding Rates on Yield and Yield Components of
Hungarian Vetch (Vicia pannonica Crantz.) Turk Journal of Agriculture and Forestry (28), 179-182

Ünver S, Kay M, Hakyemez H, Güler M, Atak M 2000. The Preliminary Study on The Effects Of Different Doses of Nitrogen and Inoculants on Yields Of Fresh Forage, Hay, Protein And Dry Matter With Protein content in Hungarian Vetch (Vicia pannonica Crantz) Anadolu, J. of AARI 10 (2) 2000, 66 - 75 MARA

Yılmaz Ş, Günel E, Sağlamtimur T 1996. Amik Ovası Ekolojik Koşullarında Yetiştirilebilecek Uygun Fĭg (Vicia spp.) Türlerinin Saptanması Üzerinde Bir Araştırma. Türkiye 3. Çayır-Mera ve Yem bitkileri Kongresi, 17-19 Haziran, Erzurum, s: 627-631 